\title{
Potassium estimation in the soil solution based on electrical conductivity and soil water content
}

\author{
Torquato M. de Andrade Neto ${ }^{1}$, Eugênio F. Coelho ${ }^{2}$, José A. do V. Santana ${ }^{3}$, \\ Edvaldo B. Santana Júnior ${ }^{3}$ \& Márcio da S. Alves ${ }^{3}$
}

\begin{abstract}
The objective of this work was to evaluate and to validate models for estimating potassium in the soil solution as a function of bulk electrical conductivity $(E C w)$, soil water content $(\theta)$ and a soil solution electrical conductivity (ECss). Treatments consisted of using three concentrations of injecting solution of potassium chloride $\left(1.0,2.5\right.$ and $\left.4.0 \mathrm{~g} \mathrm{~L}^{-1}\right)$ which were applied by two trickle irrigation systems (microsprinkler and drip) during the first cycle of the banana crop cv. Terra Maranhão. Results showed that it is feasible to estimate potassium concentration in the soil solution from data of ECss and $\theta$ obtained by time domain reflectometry (TDR) using an equation that combined a linear and a potential model. The estimated values of potassium concentration were close to the ones measured along the crop cycle under field conditions, with a mean normalized deviation of $10.0 \%$, maximum and minimum deviation of 5.0 and $13.0 \%$, respectively.
\end{abstract}

Key words: TDR, trickle irrigation, fertirrigation

\section{Estimativa de potássio na solução do solo baseada na condutividade elétrica e umidade do solo}

\begin{abstract}
RESUMO
O objetivo deste trabalho foi avaliar e validar modelo de estimativa de potássio na solução do solo, como função da condutividade elétrica aparente (CEa), da umidade do solo $(\theta)$ e da condutividade elétrica da solução do solo (CEss). Os tratamentos consistiram no uso de três concentrações de cloreto de potássio da solução de injeção $\left(1,0,2,5\right.$ e 4,0 $\left.\mathrm{g} \mathrm{L}^{-1}\right)$ aplicadas por microaspersão e por gotejamento, durante o primeiro ciclo da cultura da bananeira cultivar Terra Maranhão. Os resultados mostraram que é viável estimar a concentração de $\mathrm{K}^{+}$na solução do solo a partir de dados de $\theta$ e CEa, obtidos por meio da técnica da reflectometria no domínio do tempo (TDR) para condições de campo, com uso de equação resultante da combinação de um modelo linear e um potencial. Os valores de $\mathrm{K}^{+}$estimados se aproximaram dos medidos ao longo do ciclo da cultura da bananeira "Terra" nas condições de campo, com desvio normalizado médio de $10 \%$, desvio máximo e mínimo de 5,0 e 13,0\%, respectivamente.
\end{abstract}

Palavras-chave: TDR, irrigação localizada, fertirrigação

\footnotetext{
${ }^{1}$ Doutorando em ciências agrárias, Universidade Federal do Recôncavo Baiano (UFRB), Rua Embrapa, s/n, CEP 44380-000, Cruz das Almas, BA. Fone: (75) 3312-8021. E-mail: andradeneto@hotmail.com

${ }^{2}$ Embrapa Mandioca e Fruticultura. Rua Embrapa, s/n, CEP 44380-000, Cruz das Almas, BA. Fone: (75) 3312-8021. E-mail: eugenio@cnpmf.embrapa.br ${ }^{3}$ Universidade Federal do Recôncavo Baiano (UFRB), Campus Cruz das Almas. E-mail:zinhojaves@hotmail.com; santanajunior7@hotmail.com; marciodv2@hotmail.com
} 


\section{INTRODUCTION}

The use of fertilizers by means of irrigation water has been increasing in the irrigation districts due mainly to the increase of trickle systems and the positive effects of fertirrigation (Santana et al., 2006). Fertirrigation is being practiced without technical criteria in Brazilian irrigation districts with consequences in soil chemical properties such as transient salinity and leaching of íons with risk of groundwater contamination (Pinto, 2001). On the other hand, this technique has contributed for optimizing fertilizer use in irrigated agriculture (Oliveira \& Villas-Boas, 2008).

An adequate fertirrigation is the one in which nutrients are applied at right moment according to crop needs. The soil chemical analysis demands long time since sampling in the field. The use of the soil solution might be a good alternative that provides the knowledge of ionic state of the soil solution in a short time. The soil solution may be an alternative for obtaining nutrient levels by laboratory analysis or by using kits for fast determination of levelsof these nutrients. Nutrient levels in soil solution may also be estimated by models from bulk electrical conductivity (ECw) or soil solution electrical conductivity (ECss) (Rhoades et al., 1976; Vogeler \& Clotheir, 1996; Muñoz-Carpena et al., 2001; Santana et al., 2007).

Time domain reflectometry might be a feasible alternative in order to obtain a better precision of soil ion dynamics as for soil water dynamics (Nobório, 2001; Muñoz-Carpena et al., 2001) since it provides soil water content and bulk electrical conductivity data at different locations in the soil space along time.

Models of Rhoades et al. (1976) and Vogeler \& Clothier (1996) are the best for adjusting ECw data as a function of soil water content and ECss (Santana et al., 2007). Muñoz-Carpena et al. (2001) have obtained relations between ECss and different ions in the soil solution like nitrate (Coelho et al., 2005) and potassium (Santana et al., 2007). Also, reasonable fitting has been noticed relating ECss and ion concentration under field conditions (Muñoz-Carpena et al., 2001; Nobório, 2001; Vogeler \& Clotheir, 2001) and under controlled environment (Santana et al., 2007; Ritter et al., 2005; Regalado et al., 2005).

This work had as objective to evaluate and validate a model for estimating potassium concentration in the soil solution as a function of bulk electrical conductivity (ECw), soil water content $(\theta)$ and soil solution electrical conductivity (ECss) under field conditions.

\section{Material AND METHODS}

The work was carried out in the experimental area of Embrapa Cassava \& Tropical Fruits, located at Cruz das Almas municipality, Bahia State, (12 48" S, 3906" W, $225 \mathrm{~m})$. The climate is classified as humid to sub humid. The soil is an Yellow Alic and Distrofic Latossol silty textured with $444 \mathrm{~g} \mathrm{~kg}^{-1}$ total sand, $131 \mathrm{~g} \mathrm{~kg}^{-1}$ silt, $425 \mathrm{~g} \mathrm{~kg}^{-1}$ clay, bulk density of $1.55 \mathrm{~kg} \mathrm{dm}^{-3}$, $0.23 \mathrm{~m}^{3} \mathrm{~m}^{-3}$ soil water content at the superior limit of soil water availability and $0.16 \mathrm{~m}^{3} \mathrm{~m}^{-3}$ for inferior limit of soil water availability for the Coastal Tablelands soils of Northeast Brazil. The chemical characteristics at the beginning of the experiment were: $\mathrm{pH} 6.3$; $11.0 \mathrm{mg} \mathrm{dm}^{-3}-\mathrm{P} ; 0.06 \mathrm{cmol}_{\mathrm{c}} \mathrm{dm}^{-3}-\mathrm{K} ; 3.4 \mathrm{cmol}_{\mathrm{c}} \mathrm{dm}^{-3}-\mathrm{Ca}+\mathrm{Mg}$; $0.09 \mathrm{cmol}_{\mathrm{c}} \mathrm{dm}^{-3}-\mathrm{Na} ; 1.32 \mathrm{cmol}_{\mathrm{c}} \mathrm{dm}^{-3}-\mathrm{H}+\mathrm{Al} ; 3.56 \mathrm{cmol}_{\mathrm{c}} \mathrm{dm}^{-3}-$ sum of bases; CTC of $4.88 \mathrm{cmol}_{\mathrm{c}} \mathrm{dm}^{-3} ; 73 \%$ for base saturation.

The work was performed inside an experiment with banana crop, cv. Terra Maranhão in a 0.1 ha area to evaluate the effect of three irrigation water with different potassium chloride concentrations $\left(1.0 ; 2.5\right.$ and $\left.4.0 \mathrm{~g} \mathrm{~L}^{-1}\right)$ on chemical soil attributes. Two irrigation systems considered were: micro sprinkler with 43. $0 \mathrm{~L} \mathrm{~h}^{-1}$ emitter per four plants and drip with three $4.0 \mathrm{~L} \mathrm{~h}^{-1}$ emitters per plant in one lateral line per plant row. The amount of water per irrigation event was calculated based upon reference evapotranspiration and crop coefficients as recommended by Allen et al. (1998). Fertirrigation was applied every week and the injection solution was based on Borges \& Caldas (2004).

A parametric model was fitted to data of soil water content and electrical conductivity as a function of potassium concentration. At least twenty different values of independent and dependent variables of the model were used in the optimization process. The optimization process was based upon minimization of the sum of square differences between observed and estimated dependent variables (objective function).

\section{Model parameters for estimating electrical conductivity and potassium concentration in the soil solution}

Experimental activity was carried inside banana crop where TDR probes and water samplers were installed in the soil at depths of 0.20 and $0.40 \mathrm{~m}$ at $0.30 \mathrm{~m}$ from plant between two emitters along lateral line (drip system) and between plant and emitter (micro sprinkler). TDR probes were installed at these locations for evaluating bulk electrical conductivity $(\mathrm{ECW})$ and soil water content $(\theta)$. TDR probes of $0.10 \mathrm{~m}$ length were built (Silva et al., 2005) and soil water content was determined by Eq. 1 (Ledieu et al., 1986). Electrical conductivity of soil solution was estimated (Giese \& Tiemann, 1975) and their values were corrected to $25^{\circ} \mathrm{C}$ temperature, according to Eq. 2 proposed by Richards (1954).

$$
\theta=0,1138 \sqrt{\mathrm{ECw} \quad 0,1785}
$$

where:

$\theta \quad$ - soil water content, $\mathrm{cm}^{3} \mathrm{~cm}^{-3}$

$\mathrm{ECW}$ - soil bulk electrical conductivity

$$
\mathrm{f}_{\mathrm{T}}=1+\frac{(25 \mathrm{~T})}{49,7}+\frac{(25 \mathrm{~T})^{2}}{3.728}
$$

Soil solution samples were collected at the same time of readings of ECw and $\theta$, these readings were made every $15 \mathrm{~min}$ beginning at the suction application with a vacuum hand pump until soil solution be collected two hours after suction. Soil solution electrical conductivity (ECss) was measured by means of a desk conductivity meter and potassium concentration [K] was estimated by using a kit for quick determination (Card Horiba). The average reading of $\theta$ and $\mathrm{ECw}$ taken during soil 
solution suction in water sampler, ECss and [K] data were related by mathematical models. The model of Vogeler \& Clothier (1996) was used for estimating ECss as a function of ECw and $\theta$ according to Eq. 3:

$$
\mathrm{EC}_{\mathrm{w}}=\frac{\mathrm{ECs}-(\mathrm{a} \theta+\mathrm{b})}{\mathrm{c} \theta-\mathrm{d}}
$$

where:

ECss - soil solution electrical conductivity

$\mathrm{ECW}$ - Soil bulk electrical conductivity

a, b, c and d - parameters of Vogeler \& Clothier (1996) equation

The data of $[\mathrm{K}]$ and ECss were related by a potential function in order to yield ECss as a function $[\mathrm{K}]$ :

$$
\mathrm{ECss}=\mathrm{aK}^{\mu}
$$

The substitution of Eq. 4 in Eq. 3 resulted in the model:

$$
\mathrm{K}=\left\{\frac{1}{\alpha} \frac{[\mathrm{ECW}-(\mathrm{a} \theta-\mathrm{b})]}{(\mathrm{c} \theta-\mathrm{d})}\right\}^{\frac{1}{\mu}}
$$

\section{Statistical evaluation of model performance}

The adjustment of the mathematical model and data was accomplished by means of minimization of root square deviation among estimated and observed values. The statistical indices ME (mean errors), RMSE (root mean square error), d (Willmott agreement index) and $\mathrm{R}^{2}$ (goodness of fit) were used for model evaluation. The root mean square error (RMSE) was defined by the equation:

$$
\operatorname{RMSE}=\sqrt{\frac{1}{\mathrm{n}} \sum_{\mathrm{i}=1}^{\mathrm{n}}\left(\mathrm{O}_{\mathrm{i}}-\mathrm{E}_{\mathrm{i}}\right)^{2}}
$$

where:

$$
\begin{array}{ll}
\mathrm{n} & \text { - number of data } \\
\mathrm{Oi} & \text { - measured value } \\
\mathrm{Ei} & \text { - estimated value }
\end{array}
$$

The absolute mean error (MEA) was calculated according to the equation:

$$
\operatorname{MEA}=\frac{1}{\mathrm{n}} \sum_{\mathrm{i}=1}^{\mathrm{n}}\left(\mathrm{O}_{\mathrm{i}}-\mathrm{P}_{\mathrm{i}}\right)^{2}
$$

The normalized error mean (MEN) was also calculated:

$$
\mathrm{MEN}=\sum_{\mathrm{i}=1}^{\mathrm{n}}\left(\frac{\mathrm{K}_{\text {measured }}-\mathrm{K}_{\text {estimated }}}{\mathrm{K}_{\text {measured }}}\right) \times 100
$$

Borges et al. (2010) reported that these statistical parameters are good indicators for model efficiency. The units used for the deviations were the same as used in the evaluation of variables in order to facilitate interpretation of results (Legates \& McCabe Jr., 1999). Also a regression analysis considering measured and estimated dependent variable with zero intercept was evaluated by the angular coefficient and goodness of fit.

\section{Validation of the model under field conditions}

Soil solution samples were collected every 15 days in each plot with three replications by using water samplers installed radially to the micro sprinkle at $0.30 \mathrm{~m}$ from plant at depths of 0.20 and $0.40 \mathrm{~m}$ during one cycle of banana crop. The water samplers were installed at $0.3 \mathrm{~m}$ from plant in the direction of plant-dripper at a fixed distance of $0.15 \mathrm{~m}$ from the dripper at two depths $(0.20$ and $0.40 \mathrm{~m})$ with three replications. The porous cup of the sampler were located in the wetted volume between two drippers.

Water samples were colleted followed by a suction with a vacuum hand pump $(-70 \mathrm{kPa})$ and the suction period lasted for two hours. Afterwards, soil solution samples were taken to laboratory and ECss and $[\mathrm{K}]$ were determined. Therefore, data of ECw, ECss and $[\mathrm{K}]$ were registered at an interval of 15 days during a whole banana cycle for the three irrigation waters with different potassium chloride concentrations (1.0;2.5 and $\left.4.0 \mathrm{~g} \mathrm{~L}^{-1}\right)$.

Once the parameters for the models for estimating $[\mathrm{K}]$ as a function of $\mathrm{ECw}$ and $[\mathrm{K}]$ as a function of ECss and $\theta$ were defined (Eq. 5); the model was applied to the data of ECss, ECw and $\theta$ which were collected every 15 days along the crop cycle. The efficiency of the model for estimating [K] concentration related to the measured concentrations along banana cycle was calculated by using Nash \& Suttcliffe (1970) equation.

$$
E F=\frac{\sum_{i=1}^{n}\left(O_{i}-O_{m}\right)^{2}-\sum_{i=1}^{n}\left(O_{i}-P_{i}\right)^{2}}{\sum_{i=1}^{n}\left(O_{i}-O_{m}\right)^{2}}=1-\frac{\sum_{i=1}^{n}\left(O_{i}-P_{i}\right)^{2}}{\sum_{i=1}^{n}\left(O_{i}-P_{i}\right)^{2}}
$$

where:

$$
\begin{aligned}
& \text { EF - efficiency of the model } \\
& \mathrm{Oi} \text { - potassium measured } \\
& \mathrm{Pi} \text { - potassium estimated }
\end{aligned}
$$

Besides efficiency, RMSE and MEA were evaluated for comparing data of $[\mathrm{K}]$ observed in the field and estimated by modeling. Statistical analysis was made considering [K] observed along crop cycle and estimated at $0.30 \mathrm{~m}$ depth for the two irrigation systems by using the test for comparing means of estimated and measured values.

\section{RESULTS AND DISCUSSION}

\section{Soil solution electrical conductivity as a function of bulk electrical conductivity and soil water content}

Table 1 illustrates the adjustment of Vogeler \& Clothier (1996) model to data of ECss as a function of ECw and $\theta$ for 1.0, 2.5 
Table 1. Parameters of Vogeler \& Clothier (1996) model as a result of fitting the model to data of ECss as a function of $\mathrm{ECW}$ and $\theta$ and statistical coefficients for the different potassium chloride concentrations, considering micro sprinkler and drip irrigation systems

\begin{tabular}{|c|c|c|c|c|c|c|c|c|c|c|}
\hline \multirow{2}{*}{$\begin{array}{l}\text { Irrigation } \\
\text { system }\end{array}$} & \multirow{2}{*}{$\begin{array}{c}\mathrm{KCL} \\
\left(\mathrm{g} \mathrm{L}^{-1}\right)\end{array}$} & \multicolumn{4}{|c|}{ Parameters $^{(1)}$} & \multicolumn{5}{|c|}{ Coefficients } \\
\hline & & a & b & C & d & $\mathrm{R}^{2}$ & RMSE & MEA & $\beta^{1}$ & $R^{2^{\prime}(6)}$ \\
\hline Drip & $\begin{array}{l}1.0 \\
2.5 \\
4.0 \\
\end{array}$ & $\begin{array}{c}7.3696 \\
3.8739 \\
1.0 \mathrm{E}+06 \\
\end{array}$ & $\begin{array}{c}-3.2 \mathrm{E}+00 \\
-2.5 \mathrm{E}+00 \\
5.2 \mathrm{E}+06 \\
\end{array}$ & $\begin{array}{c}25.60 \\
18.69 \\
2.2 \mathrm{E}+06 \\
\end{array}$ & $\begin{array}{c}10.09 \\
8.08 \\
6.3 \mathrm{E}+06 \\
\end{array}$ & $\begin{array}{l}0.93 \\
0.78 \\
0.70 \\
\end{array}$ & $\begin{array}{l}1.198 \\
2.459 \\
1.432 \\
\end{array}$ & $\begin{array}{l}0.927 \\
2.085 \\
1.516 \\
\end{array}$ & $\begin{array}{l}0.99 \\
1.00 \\
1.01 \\
\end{array}$ & $\begin{array}{l}0.78 \\
0.79 \\
0.12 \\
\end{array}$ \\
\hline Micro Sprinkler & $\begin{array}{l}1.0 \\
2.5 \\
4.0\end{array}$ & $\begin{array}{c}-3.1 \mathrm{E}+08 \\
9.8 \mathrm{E}+09 \\
3.9244\end{array}$ & $\begin{array}{c}1.7 \mathrm{E}+07 \\
-3.9 \mathrm{E}+09 \\
-2.9 \mathrm{E}+00\end{array}$ & $\begin{array}{c}-9.9 \mathrm{E}+08 \\
3.0 \mathrm{E}+09 \\
18.80\end{array}$ & $\begin{array}{c}-2.2 \mathrm{E}+08 \\
1.0 \mathrm{E}+10 \\
8.13\end{array}$ & $\begin{array}{l}0.27 \\
0.19 \\
0.79\end{array}$ & $\begin{array}{l}1.733 \\
4.780 \\
2.638\end{array}$ & $\begin{array}{l}1.306 \\
4.293 \\
2.186\end{array}$ & $\begin{array}{l}1.00 \\
1.08 \\
0.99\end{array}$ & $\begin{array}{l}0.72 \\
0.34 \\
0.77\end{array}$ \\
\hline
\end{tabular}

(1) Parameters of Vogeler \& Clothier (1996) equation for estimating ECss (soil solution electrical conductivity) from ECw (bulk electrical conductivity) and $\theta$ (soil water content); (2) $\mathrm{R}^{2}$ - goodness of fit; (3) RMSE - root mean square errors; (4) MEA - mean absolute errors; (5) $b$ - angular coefficient of equation $(\mathrm{Y}=\mathrm{bX})$; ${ }^{\left({ }^{6}\right)} \mathrm{R}^{2}$ - Goodness of fit of relation ECss measured - ECss estimated by using Vogeler $\&$ Clothier (1996) model

and $4.0 \mathrm{~g} \mathrm{~L}^{-1}$ concentrations of $\mathrm{K}$ in water by micro sprinkler and drip irrigation. Results showed that 70,78 and $93 \%$ of ECss variations were due to the variation of $\mathrm{ECW}$ and $\theta$ for 4.0; 2.3 e $1.0 \mathrm{~g} \mathrm{~L}^{-1}$ concentrations, respectively, in drip system. These results were in agreement to the ones obtained by Silva et al. (2005), they verified that $92 \%$ of variation of ECss were due to variations of ECW and $\theta$ in a similar study. Santana et al. (2006) noticed that the empirical model of Vogeler \& Clothier (1996) resulted in best estimate of ECss as a function of ECw and $\theta$ compared to other models, in which, $82.7 \%$ of ECss variations was explained by ECw e $\theta$ variations.

Vogeler \& Clothier (1996) models fitted reasonably to the data of ECss as a function of ECw and $\theta$ only for $4.0 \mathrm{~g} \mathrm{~L}^{-1}$ concentration. This result is in agreement to the ones of Santana et al. (2007), who observed that $79 \%$ of ECss variation was explained by variation of ECw and $\theta$ using Vogeler \& Clothier (1996) model for a loam soil. The minimum RMSE value and the smaller MEA, which indicate the best fitting of data to Eq. 3 was verified for the irrigation water concentration of $1.0 \mathrm{~g} \mathrm{~L}^{-1}$ for drip system. The ECss model underestimated the measured values for $1.0 \mathrm{~g} \mathrm{~L}^{-1}$ concentration in case of drip system and for $4.0 \mathrm{~g} \mathrm{~L}^{-1}$ in case of micro sprinkler. The model overestimated the measured values with small fitting coefficients in case of micro sprinkler. This result did not agree to the one verified by Santana et al. (2007). These authors found that ECss from the model underestimed the measured values by about $5 \%$.

\section{Potassium concentration as a function of bulk electrical conductivity and soil water content}

Table 2 shows model parameters as a result of adjustment of Eq. 5 to potassium data as a function of $\mathrm{ECw}$ and $\theta$. Also correlation and difference coefficients are shown in the same table for both drip and sprayer systems and considering the irrigation water concentrations. Eq. 5 explained $92.42 ; 81.52$ and $84.29 \%$ of variations in $[\mathrm{K}]$ due to variations of ECw and $\theta$ for water concentrations respectively of $1.0 ; 2.5$ and $4.0 \mathrm{~g} \mathrm{~L}^{-1}$, in case of drip system. These coefficients were near to the ones obtained by Santana et al. (2007), who noticed that $81 \%$ of variations of $[\mathrm{K}]$ were explained by variations of $\mathrm{ECw}$ and $\theta$ in a sandy silty soil. The same occurred for sprayer system, i.e., the Eq. 5 explained $87,84 \mathrm{e} 80.1 \%$ of variation of $[\mathrm{K}]$ as a function of $\mathrm{ECw}$ and $\theta$ for concentrations of potassium chloride in irrigation water of 1.0, 2.5 and $4.0 \mathrm{~g} \mathrm{~L}^{-1}$. The results were in agreement to the ones of Santana et al. (2007), the model explained $81,78 \%$ of $[\mathrm{K}]$ as function of ECW and $\theta$ in a sandy silty soil.

Treatments that showed the smallest value of RMSE were the ones that presented the largest goodness of fit as observed by Borges et al. (2010), except for the concentration of $2.5 \mathrm{~g} \mathrm{~L}^{-1}$ in micro sprinkler. Eq. 5 overestimated about $2.5 \%$ the measured values of $[\mathrm{K}]$ for concentrations of $4.0 \mathrm{~g} \mathrm{~L}^{-1}$ in drip system and about $1.4 \%$ the measured values for $2.5 \mathrm{~g} \mathrm{~L}^{-1}$ concentration in micro sprinkler, however the model underestimated measured [K] values in the range of 1.16 to $1.45 \%$ for the other irrigation water concentrations in both irrigation systems.

The goodnes of fit for relations $\mathrm{K}_{\mathrm{es}}=\mathrm{b} \mathrm{K} \mathrm{K}_{\mathrm{med}}\left(\mathrm{K}_{\mathrm{es}}\right.$ - estimated potassium concentration and $\mathrm{K}_{\text {med }}$ - measured concentration) for all irrigation water concentrations were larger than those obtained by Santana et al. (2007), who worked with different models for estimating $[\mathrm{K}]$ and obtained $74 \%$ of $[\mathrm{K}]$ variations explained by ECw and $\theta$ variations. There was statistical difference of deviation modules between the averages of measured and estimated $[\mathrm{K}]$ by the $\mathrm{t}$ test, considering the three concentrations of irrigation water. Only the average deviation

Table 2. Parameters of Eq. 5 as a result of fitting the model to data of [K] as a function of ECW and $\theta$ and statistical coefficients for the different potassium chloride concentrations, considering micro sprinkler and drip irrigation systems

\begin{tabular}{|c|c|c|c|c|c|c|c|c|c|c|c|}
\hline \multirow{2}{*}{$\begin{array}{l}\text { Irrigation } \\
\text { system }\end{array}$} & \multirow{2}{*}{$\begin{array}{c}\mathrm{KCL} \\
\left(\mathrm{g} \mathrm{L}^{-1}\right)\end{array}$} & \multicolumn{4}{|c|}{ Parameters ${ }^{(1)}$} & \multicolumn{6}{|c|}{ Coefficients } \\
\hline & & a & b & C & d & $\alpha$ & $\mu$ & $\mathbf{R}^{2}$ & RMSE & MEA & $R^{2^{\prime}(5)}$ \\
\hline \multirow{3}{*}{ Drip } & 1.0 & 50.9 & $-1.9 \mathrm{E}+01$ & 62.9 & 23.9 & 0.70 & 0.06 & 0.92 & 1.198 & $0.93 \mathrm{a}$ & 0,91 \\
\hline & 2.5 & -15.8 & -7.57 & 27.1 & 11.0 & 0.12 & 0.75 & 0.81 & 2.459 & $2.08 \mathrm{~b}$ & 0.80 \\
\hline & 4.0 & 22.9 & 5.56 & -1.42 & -0.35 & 1.89 & 0.63 & 0.84 & 1.432 & $1.52 \mathrm{~b}$ & 0.72 \\
\hline \multirow{3}{*}{ Micro sprinkler } & 1.0 & $-3.1 \mathrm{E}+08$ & $-1.7 \mathrm{E}+07$ & $-9.9 \mathrm{E}+06$ & $-2,1 \mathrm{E}+08$ & 0.16 & 0.43 & 0.87 & 1.733 & $1.31 \mathrm{a}$ & 0.86 \\
\hline & 2.5 & 0.95 & 0.038 & -9.78 & -2.78 & $3.7 \mathrm{E}-06$ & 3.08 & 0.84 & 4.780 & $4.29 \mathrm{~b}$ & 0.82 \\
\hline & 4.0 & -13.6 & -8.65 & 27.4 & 11.96 & 0.20 & 0.66 & 0.80 & 2.638 & $2.18 \mathrm{a}$ & 0.78 \\
\hline
\end{tabular}


A.

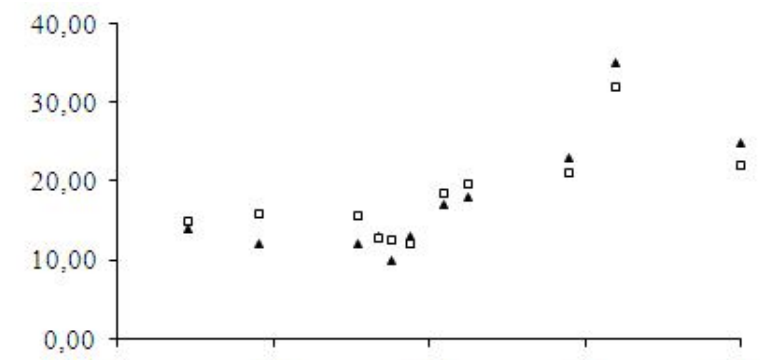

B.

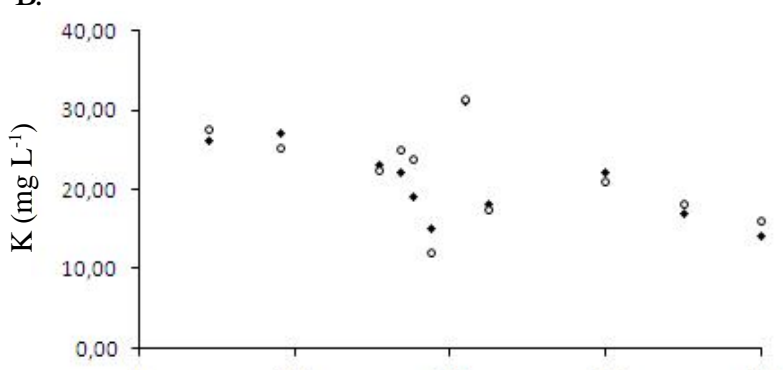

C.

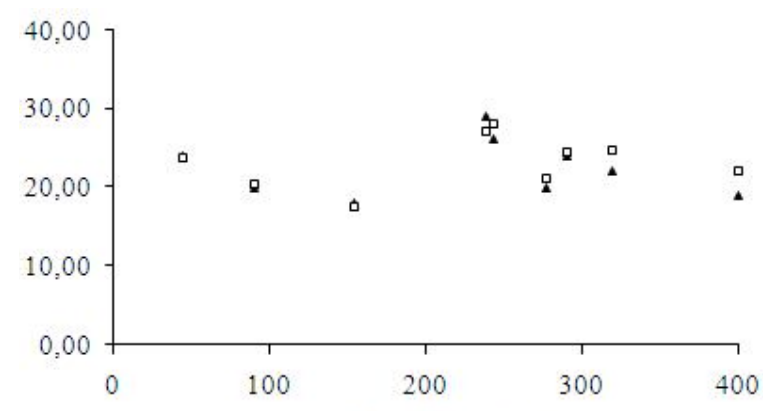

D.

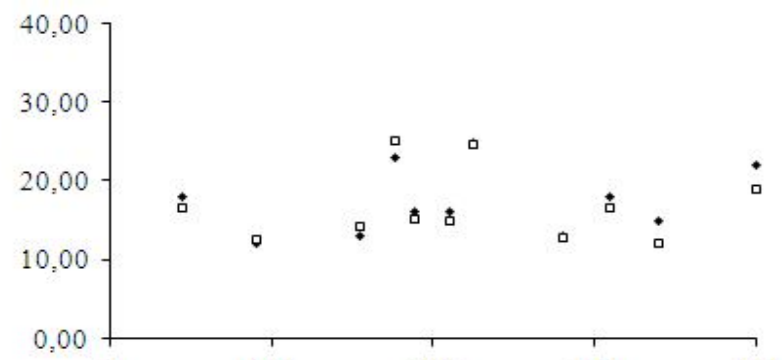

E

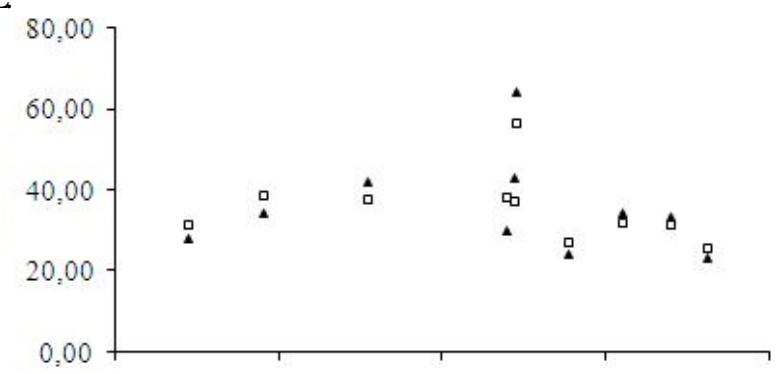

F.

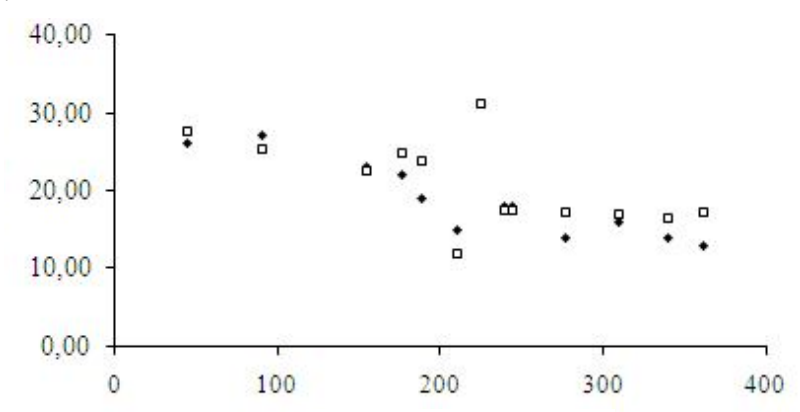

Days after planting

- $\mathrm{K}$ measured $\square \mathrm{K}$ estimated

- Kmeasured $\quad \mathrm{K}$ estimated

Figure 1. Values of measured and estimated $[\mathrm{K}]$ in the soil solution by Eq. 5 during 400 days for potassium chloride concentrations of 1.0 (A. D); 2.5 (B. E) and $4.0 \mathrm{~g} \mathrm{~L}^{-1}(\mathrm{C}$. F) in irrigation water applied by drip and micro sprinkler irrigation systems

(5.68\%) for $1.0 \mathrm{~g} \mathrm{~L}^{-1}$ concentration differed $(\mathrm{P}<0.05)$ fom the others which were close to $12,0 \%$ in case of micro sprinkler. The average deviation between $[\mathrm{K}]$ estimated and measured $(5.42 \%)$ for $4.0 \mathrm{~g} \mathrm{~L}^{-1}$ concentration was statistically different from and smaller than the others whose average deviation varied from 10.70 to $13.83 \%$ in case of drip irrigation system.

\section{Validation of the model under field conditions}

Figure 1 depicts concentrations of $[\mathrm{K}]$ observed from soil solution and estimated by Eq. 5 along time for concentrations of potassium chloride in irrigation water of $1.0 ; 2.5$ and $4.0 \mathrm{~g} \mathrm{~L}^{-1}$, in case of drip system (Figure 1A, 1B and 1C) and of micro sprinkler (Figure 1D, 1E and 1F). Eq. 5 presented efficiencies of $0.94,0.97$ and 0.94 for concentrations of $1.0 ; 2.5$ and $4.0 \mathrm{~g} \mathrm{~L}^{-1}$ in case of sprinkler system. These efficiencies were close to values obtained in case of drip indicating that the model fitted reasonably to field data for both irrigation systems (Table 3). The average variation of normalized errors (MEN) ranged from 5.0 to $13.0 \%$ for both irrigation systems.

MEN for $4.0 \mathrm{~g} \mathrm{~L}^{-1}$ irrigation water concentration differed statistically from the others by test with a value of $5.4 \%$, in case
Table 3. Performance of Eq. 5 by the statistical coefficients for the different potassium concentrations

\begin{tabular}{|c|c|c|c|c|}
\hline $\begin{array}{c}\text { Irrigation } \\
\text { system }\end{array}$ & $\begin{array}{c}\mathrm{KCL} \\
\left(\mathrm{g} \mathrm{L}^{-1}\right)\end{array}$ & $\begin{array}{l}t \text { test } \\
\text { MEN }^{(1)}\end{array}$ & $\begin{array}{l}\operatorname{RMSE}^{(2)} \\
\left(\mathrm{mg} \mathrm{L}^{-1}\right)\end{array}$ & $\mathrm{EF}^{(3)}$ \\
\hline \multirow{3}{*}{ Micro Sprinkler } & 1.0 & $5.680 \mathrm{a}$ & 1.198 & 0.94 \\
\hline & 2.5 & $12.230 \mathrm{~b}$ & 2.459 & 0.97 \\
\hline & 4.0 & $13.780 \mathrm{~b}$ & 1.432 & 0.94 \\
\hline \multirow{3}{*}{ Drip } & 1.0 & $13.830 \mathrm{a}$ & 1.733 & 0.93 \\
\hline & 2.5 & $10.704 \mathrm{a}$ & 4.780 & 0.94 \\
\hline & 4.0 & $5.420 \mathrm{~b}$ & 2.638 & 0.89 \\
\hline
\end{tabular}

of drip system. The deviation was about $11 \%$ for the other treatments (concentrations). The model efficiency stayed between 0.89 and 0.94 for drip system. The fiited values by Eq. 5 have showed dispersions (RMSE), in the range of 1,43 to $4,78 \mathrm{mg} \mathrm{L}^{-1}$.

\section{Conclusions}

1. The model of ECss as a function of ECw and soil water content underestimated measured $\mathrm{K}$ ín concentration values 
for $1.0 \mathrm{~g} \mathrm{~L}^{-1}$ potassium chloride concentration of irrigation water in drip system and for $4.0 \mathrm{~g} \mathrm{~L}^{-1}$ in micro sprinkler. The model overstimated measured values with poor fit to data for the other concentrations in case of sprinkler.

2. Eq. 5 showed larger performance coefficients for estimating potassium ion concentration compared to Eq. 3 for estimating ECss.

3. Eq. 5 showed efficiencies ranged from 0.89 to 0.97 for all concentrations of irrigation water potassium chloride, with mean variation of normalized errors of 5 to $13 \%$ in both irrigation systems.

\section{LiteRATURE CITED}

Allen, R. G.; Pereira, L. S.; Raes, D.; Smith, M. Crop evapotranspiration: Guidelines for computing crop water requirements. Rome: FAO, 1998, 297p. FAO. Irrigation and Drainage Paper, 56

Borges, A. L.; Caldas, R. C. Teores de nutrientes nas folhas de bananeira, cv. Pacovan, sob irrigação. Ciência e Agrotecnologia, v.28, p.1099-1106, 2004.

Borges, V. P.; Oliveira, A. S. de.; Coelho Filho, M. A.; Silva, T. S. M.; Pamponet, B. M. Avaliação de modelos de estimativa da radiação solar incidente em Cruz das Almas, Bahia. Revista Brasileira de Engenharia Agrícola e Ambiental, v.14, p.7480, 2010.

Coelho, E. F.; Vellame, L. M.; Coelho Filho, M. A. Sondas de TDR para estimativa da umidade e condutividade elétrica do solo com uso de multiplexadores. Revista Brasileira de Engenharia Agrícola e Ambiental, v.9, p.475-480, 2005.

Giese, K.; Tiemann, R. Determination of the complex permittivity from the sample time domain reflectometry. Advanced Molex Relaxes Processes, v.7, p.45-49, 1975.

Ledieu, J.; d. Ridder, P.; d. Cleck, P.; Dautrebande, S. A method measuring soil water moisture by time-domain reflectometry. Journal of Hydrology, v.88, p.319-328, 1986.

Legates, D. R.; McCabe Jr., G. J. Evaluating the use of "goodness-of-fit" measures in hydrologic and hydroclimatic model validation. Water Resources Research, v.35, p.233241, 1999.

Muñoz-Carpena, R.; Regalado, C. M.; Alvarez-Benedí, J.; Socorro, A. R.; Pérez, N. Determinación simultánea mediante TDR del transporte de agua y un soluto salino en el suelo. In: López, J. J.; Quemada, M. Temas de investigación en zona no saturada. 5.ed., Pamplona: Universidade Pública de Navarra, 2001. p.1-7.
Nash, J. E; Sutcliffe, J. V. River flow forecasting through conceptual models part I - A discussion of principles. Journal of Hydrology, v.10, p.282-290, 1970.

Nobório, K. Measurement of soil water content and electrical conductivity by time domain reflectometry: A review. Computers and Electronics in Agriculture, v.31, p. 213-237, 2001.

Oliveira, M. V. A. M de; Villas-Boas, R. L. Uniformidade de distribuição do potássio e do nitrogênio em sistemas de irrigação por gotejamento. Engenharia Agrícola, v.28, p 95103, 2008.

Pinto, J. M. Fertirrigação em fruticultura irrigada. Revista Irrigação \& Tecnologia Moderna, v.49, p.14-23, 2001.

Regalado, C. M.; Ritter, A.; Álvarez-Benedí, J.; Muñoz-Carpena, R. Simplified method to estimate the green-ampt wetting front suction and soil sorptivity with the Philip-dunne fallinghead Permeameter. Vadose Zone Journal, v.4, p.291-299, 2005.

Richards, L. A. Diagnosis and improvement of saline and alkali soils. Washington: United States Salinity Laboratory, 1954. 160p. USDA Agriculture Handbook, 60.

Rhoades, J. D.; Raats, P. A.; Prather, R. J. Effects of liquid phase electrical conductivity, water content and surface conductivity on bulk soil electrical conductivity. Soil Science Society of America Journal, v.40, p.651-655, 1976.

Ritter, A, R. Muñoz-Carpena, C. M. Regalado, M. Javaux; Vanclooster, M. Using TDR and Inverse modeling to characterize solute transport in a layered agricultural volcanic Soil. Vadose Zone Journal, v.4, p.300-309. 2005

Santana, G. da S.; Coelho, E. F.; Silva, T. S. M.; Ramos, M. M. Estimativa da condutividade elétrica da solução do solo a partir do teor de água e da condutividade elétrica aparente do solo. Revista Brasileira de Engenharia Agrícola, v.26, p.672-685, 2006.

Santana, G. S.; Coelho, E. F.; Silva, T. M.; Ramos, M. M. Relação entre potássio na solução do solo, umidade e condutividade elétrica aparente do solo. Revista Brasileira de Engenharia Agrícola e Ambiental, v.11, p.142-151, 2007.

Silva, T. S. M.; Coelho, E. F.; Paz, V. P. S.; Vellame, L. M.; Santana, G. S. Teor de potássio na solução do solo com uso da técnica de reflectometria no domínio do tempo. Revista Irriga, v.10, p.393-402, 2005.

Vogeler, I.; Clothier, B. E. Characterizing water and solute movement by TDR and disk permeametry. Soil Science Society of America Journal, v.60, p.5-12, 1996.

Willmott, C. J. On the validation of models. Physical Geography, v.2, p.184-94, 1981. 